\title{
A Model to Choose Hub and Route Determination
}

\author{
K. Kevin a*, Y. M. Kinley Aritonang a, Julius Dharma Lesmono ${ }^{b}$ \\ a Department of Industrial Technology, Parahyangan Catholic University, Bandung, Indonesia \\ Jl. Ciumbuleuit No.94, Hegarmanah, Kec. Cidadap, Kota Bandung, Jawa Barat, Indonesia \\ b Department of Mathematics, Parahyangan Catholic University, Bandung, Indonesia \\ Jl. Ciumbuleuit No.94, Hegarmanah, Kec. Cidadap, Kota Bandung, Jawa Barat, Indonesia \\ *Corresponding author: marcelius.kevins@gmail.com
}

\section{ARTICLE INFO}

Article history

Received June 3, 2019

Revised July 29, 2019

Accepted August 20, 2019

Available Online August 31, 2019

\section{Keywords}

Strategic decisions

Choosing hub

Distribution process

VRP

\begin{abstract}
Determining a transport hub is a strategic decision to build a good distribution flow. In this paper, We suggested a model for choosing hub locations as sources for companies. In previous studies, The determination of hub locations with a vehicle routing problem is not integrated. Therefore, this study built a model to assess the position of the hubs by considering the budget. The business should have a decision on vehicle routing with hubs to reduce total transport costs. In addition, the method of distribution of goods for hubs and non-hubs with third-party logistics was determined by the use of a vehicle routing problem. The optimal weight was obtained through the analysis of sensitivity. In the sensitivity analysis, this study found that the best choice in this study was to use a weight of 0.9-1.0. It provides the lowest total cost of transport.
\end{abstract}

This is an open-access article under the CC-BY-SA license.

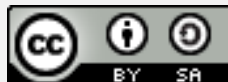

\section{Introduction}

Based on a survey in 2016, Farber [1] found that online purchases have significantly increased. The business-to-consumer retail segment continues to grow on online shopping [2]. The growth of e-commerce provided the Logistics Company with an opportunity. The new logistics company does not usually have significant capital. The capital limitation makes it difficult to determine the hub that needs to be built. Hub is a particular facility that functions as a point transfer facility [3]. Based on these benefits, the company has more power to develop its market to compete with other companies. There are several alternatives to consider in setting up hubs to avoid the wrong decision. It leads to an adverse impact on the company. Besides, the new logistics company does not know the route of the vehicle that must be selected and passed to minimize logistics costs. The right decisions, a company, have the advantage of a hub building and minimizing the total transportation costs. The Vehicle Routing Problem (VRP) model was first introduced by Dantzig and Ramser [4]. Min [5] Developed multiple vehicle routing problems by considering pickup, delivery size, and traffic congestion. Baldacci, et 
al. [6] and Domínguez-Martín, et al. [7] proposed routing for the heterogeneous fleet of the vehicle. El-Sherbeny [8] developed a model with a homogeneous product component. In the generalized vehicle routing problem (GVRP), the set of customers is divided into clusters, and each cluster has a specific demand [9-14]. The objective is to a minimum cost set of delivery routes that serve the total demand of customers served by a single vehicle that does not exceed the vehicle capacity. The green vehicle routing problem (GVRP) have proposed by Erdoğan and Miller-Hooks [15], Koç and Karaoglan [16], Montoya, et al. [17] and Andelmin and Bartolini [18] charging an EV was done in constant time. Another problem is that the charging time linearly depends on the state of the EV at its arrival [17, 19-22]. There is an E-VRP with Capacitated Charging Station by Froger, et al. [23].

In common, the companies manage the different hub assignment problems included selecting and allocating hubs. Companies assign nodes to transfer one of the hubs. In several studies, both location and allocation are known as NP-hard problems [24]. Regarding the determination of hubs, Klincewicz [25] was the first to discuss the location hubs. The integration of operational, tactical, and strategic decisions requires further elaboration [26-28]. Various criteria and aspects are the problems to improve. According to Weber [14], the concept of choosing a warehouse location for the first time by placing the warehouse is a way that the total distance traveled between the warehouse and the customer can be minimized. According to Vieira and Luna [27], different aspects can be considered during modeling as decision criteria or model restrictions. They consist of 1). Transportation; 2 . Hub functionality; 3. Investment; 4. Offers and requests; 5. Markets; 6. Policy; and 7. Environment. Alumur, et al. [29], Campbell and O'Kelly [26], and Martí, et al. [30] used p-hub median and Farahani, et al. [31] used p-hub covering.

Although some research has been carried out on p-hub and VRP, no studies have been found which use 2-stage in this problem. The first stage was that the analysis process is carried out with distance and weighted demand and investment in limited capital. In the second stage, we analyzed the costs by implementing vehicle routing problems. This research aims to develop a mathematical model of the total cost of hubs and transportation by considering distance, demand, and investment and determining the vehicle's route to minimize transportation costs. The innovation of this analysis is a model that combines the selection of hubs with vehicle routing problems. The model to be selected by a business is an ideal hub with capital constraints to achieve minimal transport costs. Organizations do have an optimum hub and an optimum vehicle routing to reduce overall travel costs to make more profit. The remainder of the paper is structured as follows. The following section focuses on model development and data used. Section 3 provides the result and discussion along with the sensitivity analysis. Conclusions and directions for future research are assigned to the last section.

\section{Methods}

\subsection{Assumptions}

In this model, Determining the hub is a strategic decision that needs to be carefully considered. The company does not have a sufficient vehicle route to reduce transport costs. Several of the assumptions are used as follows: 1). Capacity meets the entire demand; 2). Vehicles have a uniform capacity, and 3). Alternatives to the hub location are available. 


\subsection{Model Development}

In this research, there were some notations that researchers use. These notations are components of the model designed. Therefore, the model can run well. The notations are:

$\mathrm{c}_{\mathrm{ij}} \quad$ : Transportation costs incurred when the vehicle moves from node $\mathrm{i}$ to node $\mathrm{j}$

$\mathrm{x}_{\mathrm{ijk}} \quad$ : Decision variables in VRP,

$$
\mathrm{x}_{\mathrm{ijk}}=\left\{\begin{array}{l}
1, \text { if vehicle } \mathrm{k} \text { moves from node } \mathrm{i} \text { to } \mathrm{j} \\
0, \text { otherwise }
\end{array}\right.
$$

$\mathrm{J}_{\mathrm{i}} \quad$ : The distance between the hub

V : Number of vehicles

Y : Total Capital

$\mathrm{N} \quad$ : Number of nodes (hub and non-hub)

$\mathrm{q}_{\mathrm{i}} \quad$ : Capacity of vehicle-i

$\mathrm{d}_{\mathrm{i}} \quad$ : The demand of customer on hub-i

$\mathrm{I}_{\mathrm{i}} \quad$ : Cost of making hub-i

$\Omega \quad$ : Weight distance

M : Capital budget or making hubs

$\mathrm{H}_{\mathrm{i}} \quad$ : Hub-i

$\mathrm{L}_{\mathrm{i}} \quad$ : The cost of $3^{\text {rd }}$ party logistics when the hub is not built

$\mathrm{a}_{\mathrm{i}} \quad$ : The weight value of hub-i

$\mathrm{b}_{\mathrm{ij}} \quad$ : Ranking value,

$\mathrm{P} \quad$ : Income / unit

$$
b_{i j}=\left\{\begin{array}{l}
1, \text { if weight value of hub }-\mathrm{i} \geq \text { hub }-\mathrm{j} \\
0, \text { otherwise }
\end{array}\right.
$$

E : Transportation cost $/ \mathrm{km}$

$\mathrm{W}_{\mathrm{i}} \quad$ : The capacity of $3^{\text {rd }}$ party logistics-i

$\mathrm{F}_{\mathrm{i}} \quad$ : The decision variable on $3^{\text {rd }}$ party logistics,

$$
F_{i}=\left\{\begin{array}{l}
1, \text { if a hub is built } \\
0, \text { if a hub is not built }
\end{array}\right.
$$

The first model is a model designed to maximize capital to evaluate the center to be constructed. The decision process is based on the weight of the distance and the weight of the request. Therefore, each company can choose which weight is better suited to reduce the overall cost of transport. The first iteration is the following one.

$\operatorname{Max} \mathrm{Y}=\sum_{i=1}^{N} \mathrm{H}_{i}$

Subject to,

$H_{i}=\sum_{\substack{i \neq j \\ j=1}}^{N} b_{i j}$

$b_{i j}=\left\{\begin{array}{cc}1, & a_{i}>a_{j} \\ 0, & a_{i}<a_{j}\end{array}\right.$

$a_{i}=\mathrm{d}_{i}(1-\Omega) \mathrm{p}-\mathrm{J}_{i} \Omega \mathrm{E}$

$\sum_{i=1}^{N} \mathrm{H}_{i} \mathrm{I}_{i} \leq \mathrm{M} ; \forall_{i} \in \mathrm{N}$

$\Omega \in(0,1)$ 
Equation (2) is the cumulative number of ranking values for each hub after comparing the weight values between hubs made. Equation (3) is the process of assigning ranking values, which 1 if the weight of the $i^{\text {th }}$-hub is greater than the value of the weight of the $\mathrm{j}^{\text {th }}$-hub and 0 otherwise. Equation (4) is an equation for calculating the weight for each prospective hub where each criterion has a weight. There are two weights used in this study, $\Omega$ for distance and $1-\Omega$ for request. Constraint (5) ensures that each hub to be built does not exceed the capital budget for constructing a hub. Constraint (6) explains that $\Omega$ is a weight value between 0 and 1 . After determining which hub to be built, the transportation costs will be calculated based on the predetermined hub(s) and non-hub(s).

The total transportation costs in the VRP are based on El-Sherbeny [8] with some modifications. The researchers added the cost of third-party logistics when there are non-hubs in a company, and the company must deliver the goods. The total transportation cost model in the VRP is the following.

$\operatorname{Min} \mathrm{Z}=\sum_{\mathrm{k}=1}^{\mathrm{V}} \sum_{\mathrm{i}=1}^{\mathrm{N}} \sum_{\mathrm{j}=1}^{\mathrm{N}} \mathrm{c}_{\mathrm{ij}} \mathrm{x}_{\mathrm{ijk}}+\sum_{\mathrm{i}=1}^{\mathrm{N}} \mathrm{d}_{\mathrm{i}} \mathrm{L}_{\mathrm{i}} \mathrm{F}_{\mathrm{i}}$

Subject to,

$\sum_{\mathrm{k}=1}^{\mathrm{V}} \sum_{\mathrm{j}=1}^{\mathrm{N}} \mathrm{x}_{\mathrm{ijk}}=1 ; \forall \mathrm{i} \in \mathrm{N}$

$\sum_{\mathrm{i}=1}^{\mathrm{N}} \mathrm{d}_{i} \sum_{\mathrm{j}=1}^{\mathrm{N}} \mathrm{x}_{\mathrm{ijk}} \leq \mathrm{q}_{\mathrm{i}} ; \forall \mathrm{k} \in \mathrm{V}$

$\sum_{j=1}^{N} x_{0 j k}=1, \forall k \in V$

$\sum_{\mathrm{i}=1}^{\mathrm{N}} \mathrm{x}_{\mathrm{ihk}}-\sum_{\mathrm{j}=1}^{\mathrm{N}} \mathrm{x}_{\mathrm{hjk}}=0, \forall \mathrm{h} \in \mathrm{N}, \forall \mathrm{k} \in \mathrm{V}$

$\sum_{i=1}^{N} x_{i, n+1, k}=1, \forall k \in V$

$x_{i j k} \in\{0,1\}, \forall i, j \in \mathrm{N}, \forall k \in V$

$\sum_{\mathrm{i}=1}^{\mathrm{N}} \mathrm{d}_{\mathrm{i}} \mathrm{F}_{\mathrm{i}} \leq \mathrm{W}_{\mathrm{i}} \mathrm{F}_{\mathrm{i}} ; \forall \mathrm{i} \in \mathrm{N}$

The objective function (7) is the cost of transportation and costs third-party logistics. It is the sum of multiplication of each move from vehicle $\mathrm{k}$ to position $\mathrm{j}\left(\mathrm{x}_{\mathrm{ijk}}\right)$ with transportation costs of moving from position $\mathrm{i}$ to position $\mathrm{j}\left(\mathrm{c}_{\mathrm{ij}}\right)$ and costs to using third-party logistics for every request on a non-hub. According to El-Sherbeny [8], constraint (8) indicates there is only one vehicle that departs from position $i$ to position $j$ with vehicle $\mathrm{k}$. Constraint (9) indicates that no vehicle is filled exceeding its capacity. Constraints (10-12) guarantee that each vehicle leaves node 0. After arriving at the customer destination vehicle can leave again, and the vehicle eventually stops at node $\mathrm{n}$ +1 . Constraint (10) sums up the displacement of each vehicle $V$ to go to position $\mathrm{j}$ from node $0\left(\mathrm{x}_{0 \mathrm{jk}}\right)$ and must be equal to one. Constraint (11) sums up each vehicle $\mathrm{V}$ departing from the initial position $i$ towards the customer $h$ then subtracting the number of each vehicle $\mathrm{V}$ departing from the customer $\mathrm{h}$ 'to the next position $\mathrm{j}\left(\mathrm{x}_{\mathrm{hjk}}\right)$ and must be 0 . Constraint (13) is the integrality for the variable decision. This constraint ensures that the value of the displacement for each vehicle $\mathrm{V}$ from position $\mathrm{i}$ to position $\mathrm{j}$ always be worth one or zero. Constraint (14) is a limitation when third party logistics for the 
second hub, a non-hub, cannot accommodate some items in the warehouse it owns, where $d_{i}$ is requested on non-hubs.

\subsection{The Data Collection}

Capital for the construction of hubs owned by a company was $25,000,000,000$ IDR. It was presumed that each hub has a requirement of $600 \mathrm{~m}^{2}$ for the same location. The data was taken from www.rumah123.com. Each area of the different buildings was converted to the same area. The transportation cost for Long Box CDD truck vehicles was 150,000 IDR. Consumption cost was 12,000 IDR, the usage cost of a vehicle was Rp. $1,000,000$, IDR, and there are also revenues for each demand for 20,000 IDR. Table 1 is the distance between nodes in the distribution network generated by the Bing map. Table 2 gives the data on demand, cost of building hub, and warehouse capacity in thirdparty logistics.

Table 1. Distance Between Nodes

\begin{tabular}{llllllllllll}
\hline & Jakarta & Bogor & Bandung & Banten & Bekasi & Depok & $\begin{array}{l}\text { Kara- } \\
\text { wang }\end{array}$ & Malang & $\begin{array}{l}\text { Sura- } \\
\text { baya }\end{array}$ & $\begin{array}{l}\text { Tang- } \\
\text { erang }\end{array}$ & $\begin{array}{l}\text { Yogya- } \\
\text { karta }\end{array}$ \\
\hline Jakarta & 0.00 & 59.95 & 152.97 & 109.13 & 21.62 & 41.69 & 82.64 & 865.16 & 798.24 & 29.28 & 550.02 \\
Bogor & 60.51 & 0.00 & 179.90 & 159.08 & 59.85 & 38.51 & 129.30 & 892.10 & 825.17 & 79.23 & 576.95 \\
Bandung & 157.01 & 181.90 & 0.00 & 258.86 & 133.78 & 163.64 & 172.52 & 812.57 & 745.65 & 179.01 & 401.39 \\
Banten & 109.91 & 161.20 & 256.69 & 0.00 & 136.58 & 130.21 & 206.09 & 968.88 & 901.96 & 92.46 & 653.74 \\
Bekasi & 23.36 & 58.89 & 136.51 & 136.17 & 0.00 & 40.64 & 68.28 & 848.71 & 781.79 & 56.32 & 533.56 \\
Depok & 43.13 & 26.55 & 162.52 & 129.55 & 42.47 & 0.00 & 111.92 & 874.72 & 807.80 & 49.70 & 559.57 \\
Karawang & 82.83 & 129.89 & 171.07 & 206.85 & 67.20 & 111.64 & 0.00 & 883.27 & 816.34 & 105.56 & 568.12 \\
Malang & 862.81 & 887.70 & 807.98 & 964.66 & 839.58 & 869.44 & 878.32 & 0.00 & 99.80 & 884.81 & 391.81 \\
Surabaya & 798.62 & 823.51 & 743.79 & 900.47 & 775.40 & 805.26 & 814.14 & 101.14 & 0.00 & 820.62 & 327.62 \\
Tangerang & 29.93 & 81.22 & 176.71 & 93.07 & 56.60 & 50.23 & 126.11 & 888.90 & 821.98 & 0.00 & 573.75 \\
Yogyakarta & 553.58 & 578.46 & 400.47 & 655.42 & 530.35 & 560.21 & 569.09 & 394.77 & 327.84 & 575.58 & 0.00 \\
\hline
\end{tabular}

Table 2. Data on demand, cost of building hub, and warehouse capacity

\begin{tabular}{cccc}
\hline Hub & Demand (unit) & $\begin{array}{c}\text { Cost of Building (Million } \\
\text { Warehouse Capacity } \\
\text { (Unit) }\end{array}$ & $\begin{array}{c}\text { War } \\
\text { Bogor }\end{array}$ \\
Bandung & 350 & 6,000 & 1,000 \\
Banten & 800 & 6,546 & 1,500 \\
Bekasi & 250 & 1,175 & 1,250 \\
Depok & 600 & 4,320 & 1,600 \\
Karawang & 450 & 6,600 & 1,450 \\
Malang & 350 & 4,560 & 1,350 \\
Surabaya & 625 & 4,350 & 1,625 \\
Tangerang & 725 & 8,182 & 1,725 \\
Yogyakarta & 800 & 4,600 & 1,800 \\
\hline
\end{tabular}

\subsection{Implementation}

In the implementation, it was assumed that a company could weigh more ondemand compared to distance. Therefore, the weight value for distance $(\Omega)$ was 0.2 , and the weight for demand (1- $\Omega$ ) was 0.8 . The reason was that the companies have a preference to prioritize customer service compared to the distance that must be taken. In addition, demand data and mileage were assumed per year for calculations in equation (4). This problem was solved by using LINGO 17.0 x64 bit software. 


\section{Results and Discussion}

The results of applying the problem into the research model determine the hub by considering the vehicle routing problem model, distance, and demand. There are five hubs chosen to be built, namely hubs in Bandung, Banten, Bekasi, Depok, and Tangerang. The total transportation costs and fees for third-party logistics for non-hubs is 72,501,500 IDR. Moreover, the total cost of constructing the hub required is $21,201,000,000$ IDR. The routing of the vehicle with a weight of 0.8 can be seen in Table 3 and Table 4. According to Jokar [32], requests in an area depend on facilities in the area. We can see from Table 3 that the chosen hub has a significant demand in weight value of $0-0,8$.

To determine the output model as expected and to know the optimal weight to minimize cost, the study carried out sensitivity analysis. There are two weights in determining the hub to be built. The weight of distance is the distance between the distribution center to the hub, and the weight of demand is the total number of demands on a hub. In this test, weight changes see the response to the model results from 0 to 1 with incremental of 0,1 , and the result in Table 3 .

Table 3. Result of Weight Sensitivity Analysis

\begin{tabular}{|c|c|c|c|c|}
\hline \multicolumn{2}{|c|}{ Weight Value } & \multirow[b]{2}{*}{ Location of Built Hub } & \multirow{2}{*}{$\begin{array}{c}\text { Amount of } \\
\text { Capital Req. } \\
(1,000,000) \text { IDR }\end{array}$} & \multirow{2}{*}{$\begin{array}{c}\text { Total of } \\
\text { Transportation Cost } \\
(10,000) \text { IDR }\end{array}$} \\
\hline Distance & Demand & & & \\
\hline 0 & 1 & $\begin{array}{l}\text { Bandung. Banten. Malang. Surabaya } \\
\text { dan Tangerang }\end{array}$ & $23,888.00$ & $9,081.3$ \\
\hline 0.1 & 0.9 & $\begin{array}{l}\text { Bandung. Banten. Bekasi. Surabaya } \\
\text { dan Tangerang }\end{array}$ & $23,888.00$ & $8,878.14$ \\
\hline 0.2 & 0.8 & $\begin{array}{c}\text { Bandung. Banten. Bekasi. Surabaya } \\
\text { dan Tangerang }\end{array}$ & $23,888.00$ & $8,878.14$ \\
\hline 0.3 & 0.7 & $\begin{array}{l}\text { Bandung. Banten. Bekasi. Surabaya } \\
\text { dan Tangerang }\end{array}$ & $24,376.00$ & $8,878.14$ \\
\hline 0.4 & 0.6 & $\begin{array}{c}\text { Bandung. Banten. Bekasi. Depok dan } \\
\text { Tangerang }\end{array}$ & $21,201.00$ & $7,250.15$ \\
\hline 0.5 & 0.5 & $\begin{array}{c}\text { Bandung. Banten. Bekasi. Depok dan } \\
\text { Tangerang }\end{array}$ & $21,201.00$ & $7,250.15$ \\
\hline 0.6 & 0.4 & $\begin{array}{c}\text { Bandung. Banten. Bekasi. Depok dan } \\
\text { Tangerang }\end{array}$ & $21,201.00$ & $7,250.15$ \\
\hline 0.7 & 0.3 & $\begin{array}{c}\text { Bandung. Banten. Bekasi. Depok dan } \\
\text { Tangerang }\end{array}$ & $21,201.00$ & $7,250.15$ \\
\hline 0.8 & 0.2 & $\begin{array}{c}\text { Bandung. Banten. Bekasi. Depok dan } \\
\text { Tangerang }\end{array}$ & $21,201.00$ & $7,250.15$ \\
\hline 0.9 & 0.1 & $\begin{array}{l}\text { Bogor Banten. Bekasi. Depok dan } \\
\text { Tangerang }\end{array}$ & $21,255.00$ & $7,085.19$ \\
\hline 1 & 0 & $\begin{array}{c}\text { Bogor Banten. Bekasi. Depok dan } \\
\text { Tangerang }\end{array}$ & $22,695.00$ & $7,085.19$ \\
\hline
\end{tabular}

Table 3 explains the amount of capital needed and the estimation of the overall transport costs. When the weight values are at (distance) $0.1-0.3$, there is a disparity in the range compared to the previous weight value. There are variations in the ranking between or before the values of the weights. Weight values at (distance) 0.4-0.8 give a difference in the range compared to the value of the previous weight. There is a difference in the rating between the weight values or the previous one. The last with a weight value of 0.9-1 discrepancy exists compared to the value of the previous weight. There is a disparity in rating between the value of the weight or the previous one. It concluded that there are four variations in the range of hubs that are established when 
changes in weight values occur. The optimal routing is presented in Table 4. Routing determination for assigned vehicles from the distribution center to each hub and nonhub is performed separately.

Table 4. Routing

\begin{tabular}{cccc} 
Weight & Vehicle & Hub Route & Non-Hub Route \\
& 1 & Jakarta - Banten - Jakarta & Jakarta - Karawang - Bogor - Tangerang - Jakarta \\
$0-1$ & 2 & Jakarta - Bekasi - Depok - Jakarta & Jakarta - Jogyakarta - Bandung - Jakarta \\
& 3 & Jakarta - Surabaya - Malang - Jakarta & - \\
\hline $0.2-0.3$ & 1 & Jakarta - Bekasi - Banten - Tangerang - Jakarta & Jakarta - Depok - Bogor - Jakarta \\
& 2 & Jakarta - Bandung - Surabaya - Jakarta & Jakarta - Yogyakarta - Malang - Karawang - Jakarta \\
\hline $0.4-0.8$ & 1 & Jakarta - Bekasi - Banten - Tangerang - Jakarta & Jakarta - Bogor - Kawarang - Jakarta \\
& 2 & Jakarta - Bandung - Depok - Jakarta & Jakarta - Jogyakarta - Surabaya - Malang - Jakarta \\
\hline & 1 & Jakarta - Bekasi - Depok - Bogor - Jakarta & Jakarta - Bandung - Karawang - Jakarta \\
\hline
\end{tabular}

\section{Conclusions}

The mathematical model in determining the location of hubs by considering distance, demand, and investment has developed with the route to minimize transportation costs. The proposed model effectively minimizes transportation costs. According to the case above, the ideal distance weight suggested for the problem is to use a distance weight of 0.9-1 with the smallest capital cost needed. Nevertheless, this weight is only a choice for a company to increase profits based on reducing overall transport costs and expenditure. There are a few avenues for further study. Next, adding additional criteria for creating hubs, such as legislation, work ethic, and others would be an exciting subject to be explored. Second, the introduction of a penalty fee where thirdparty logistics cannot satisfy all requests makes the model more realistic.

\section{References}

[1] M. Farber. (2016, 1 January). Retail: online shopping.

[2] A. Garcia, "Amazon prime day shattered global sales records," in CNN Money, ed, 2015.

[3] G. Ozbaygin, O. E. Karasan, M. Savelsbergh, and H. Yaman, "A branch-and-price algorithm for the vehicle routing problem with roaming delivery locations,"

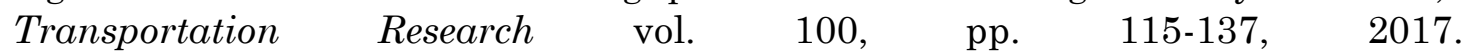
https://doi.org/10.1016/j.trb.2017.02.003.

[4] G. B. Dantzig and J. H. Ramser, "The truck dispatching problem," Management science, vol. 6, pp. 80-91, 1959. https://doi.org/10.1287/mnsc.6.1.80.

[5] H. Min, "The multiple vehicle routing problem with simultaneous delivery and pick-up points," Transportation Research Part A: General, vol. 23, pp. 377-386, 1989. https://doi.org/10.1016/0191-2607(89)90085-X.

[6] R. Baldacci, M. Battarra, and D. Vigo, "Routing a heterogeneous fleet of vehicles," in The vehicle routing problem: latest advances and new challenges, ed: Springer, 2008, pp. 3-27. 
[7] B. Domínguez-Martín, I. Rodriguez-Martin, and J.-J. Salazar-Gonzalez, "The driver and vehicle routing problem," Computers \& Operations Research, vol. 92, pp. 56-64, 2018. https://doi.org/10.1016/j.cor.2017.12.010.

[8] N. A. El-Sherbeny, "Vehicle routing with time windows: An overview of exact, heuristic and metaheuristic methods," Journal of King Saud University-Science, vol. 22, pp. 123-131, 2010. https://doi.org/10.1016/j.jksus.2010.03.002.

[9] T. Bektaş, G. Erdoğan, and S. Røpke, "Formulations and branch-and-cut algorithms for the generalized vehicle routing problem," Transportation Science, vol. 45, pp. 299-316, 2011. https://doi.org/10.1287/trsc.1100.0352.

[10] M. Fischetti, J. J. S. González, and P. Toth, "The symmetric generalized traveling salesman polytope," Networks, vol. 26, pp. 113-123, 1995. https://doi.org/10.1002/net.3230260206.

[11] M. Fischetti, J. J. Salazar González, and P. Toth, "A branch-and-cut algorithm for the symmetric generalized traveling salesman problem," Operations Research, vol. 45, pp. 378-394, 1997. https://doi.org/10.1287/opre.45.3.378.

[12] A. Montoya, C. Guéret, J. E. Mendoza, and J. G. Villegas, "A multi-space sampling heuristic for the green vehicle routing problem," Transportation Research Part C: Emerging Technologies, vol. 70, pp. 113-128, 2016. https://doi.org/10.1016/j.trc.2015.09.009.

[13] C. E. Noon and J. C. Bean, "A Lagrangian based approach for the asymmetric generalized traveling salesman problem," Operations Research, vol. 39, pp. 623632, 1991. https://doi.org/10.1287/opre.39.4.623.

[14] A. Weber, Ueber den standort der industrien vol. 1: Рипол Классик, 1909.

[15] S. Erdoğan and E. Miller-Hooks, "A green vehicle routing problem,"

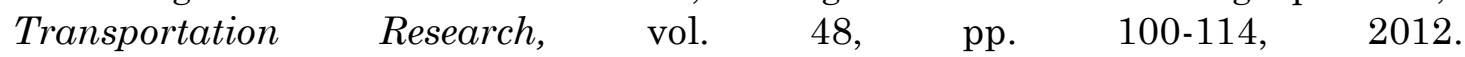
https://doi.org/10.1016/j.tre.2011.08.001.

[16] Ç. Koç and I. Karaoglan, "The green vehicle routing problem: A heuristic based exact solution approach," Applied Soft Computing, vol. 39, pp. 154-164, 2016. https://doi.org/10.1016/j.asoc.2015.10.064.

[17] A. Montoya, C. Guéret, J. E. Mendoza, and J. G. Villegas, "The electric vehicle routing problem with nonlinear charging function," Transportation Research, vol. 103, pp. 87-110, 2017. https://doi.org/10.1016/j.trb.2017.02.004.

[18] J. Andelmin and E. Bartolini, "An exact algorithm for the green vehicle routing problem," Transportation Science, vol. 51, pp. 1288-1303, 2017. https://doi.org/10.1287/trsc.2016.0734.

[19] G. Desaulniers, F. Errico, S. Irnich, and M. Schneider, "Exact algorithms for electric vehicle-routing problems with time windows," Operations Research, vol. 64, pp. 1388-1405, 2016. https://doi.org/10.1287/opre.2016.1535.

[20] G. Hiermann, J. Puchinger, S. Ropke, and R. F. Hartl, "The electric fleet size and mix vehicle routing problem with time windows and recharging stations," European Journal of Operational Research, vol. 252, pp. 995-1018, 2016. https://doi.org/10.1016/j.ejor.2016.01.038.

[21] M. Keskin and B. Çatay, "Partial recharge strategies for the electric vehicle routing problem with time windows," Transportation Research, vol. 65, pp. 111127, 2016. https://doi.org/10.1016/j.trc.2016.01.013.

[22] L. V. Snyder and M. S. Daskin, "A random-key genetic algorithm for the generalized traveling salesman problem," European journal of operational research, vol. 174, pp. 38-53, 2006. https://doi.org/10.1016/j.ejor.2004.09.057. 
[23] A. Froger, J. E. Mendoza, O. Jabali, and G. Laporte, "A matheuristic for the electric vehicle routing problem with capacitated charging stations," 2017. https://hal.archives-ouvertes.fr/hal-01559524/document.

[24] F. Ibrahim and A. Rusdiansyah, "Model Hub Median Problem Dengan Batasan Travel Time," Jurnal Teknik Industri, vol. 18, pp. 1-8, 2017. https://doi.org/10.22219/JTIUMM.Vol18.No1.1-8.

[25] J. G. Klincewicz, "Hub location in backbone/tributary network design: a review," Location Science, vol. 6, pp. 307-335, 1998. https://doi.org/10.1016/S09668349(98)00042-4.

[26] J. F. Campbell and M. E. O'Kelly, "Twenty-five years of hub location research," $\begin{array}{lllll}\text { Transportation Science, } & \text { vol. 46, pp. }\end{array}$ https://doi.org/10.1287/trsc.1120.0410.

[27] C. L. d. S. Vieira and M. M. M. Luna, "Models and methods for logistics hub location: a review towards transportation networks design," Pesquisa Operacional, vol. 36, pp. 375-397, 2016. http://dx.doi.org/10.1590/01017438.2016.036.02.0375

[28] M. T. Melo, S. Nickel, and F. Saldanha-Da-Gama, "Facility location and supply chain management-A review," European journal of operational research, vol. 196, pp. 401-412, 2009. https://doi.org/10.1016/j.ejor.2008.05.007.

[29] S. A. Alumur, B. Y. Kara, and O. E. Karasan, "Multimodal hub location and hub network design," Omega, vol. 40, pp. 927-939, 2012. https://doi.org/10.1016/j.omega.2012.02.005.

[30] R. Martí, Á. Corberán, and J. Peiró, "Scatter search for an uncapacitated p-hub median problem," Computers \& Operations Research, vol. 58, pp. 53-66, 2015. https://doi.org/10.1016/j.cor.2014.12.009.

[31] R. Z. Farahani, M. SteadieSeifi, and N. Asgari, "Multiple criteria facility location problems: A survey," Applied Mathematical Modelling, vol. 34, pp. 1689-1709, 2010. https://doi.org/10.1016/j.apm.2009.10.005.

[32] M. R. A. Jokar, "Facility and hub location model based on gravity rule," Computers \& Industrial Engineering, vol. 109, pp. 28-38, 2017. https://doi.org/10.1016/j.cie.2017.04.005. 